\title{
AZ ESG-MUTATÓK VÁLLALATI VÁLSÁGÁLLÓSÁGRA GYAKOROLT HATÁSA A KORONAVÍRUS-JÁRVÁNY ALATT' ${ }^{1}$
}

Dudás Fanni - Naffa Helena ${ }^{2}$

\begin{abstract}
ABSZTRAKT
$\mathrm{Az}$ új koronavírusjárvány kitörése tagadhatatlan hatással volt a társadalomra, a közegészségügyre és a globális piacokra. Jelen kutatás keretében megvizsgáltuk, hogy a vállalatok különböző környezeti (E), szociális (S) és kormányzati (G) mutatói, amelyeket együttesen ESG-mutatóknak nevezünk, milyen hatást gyakorolnak a vállalatok válságállóságára. Empirikus teszteket végeztünk el az MSCI World Index közel 1000 vállalatára a 2020. február és 2020. május közötti időszakra. A vizsgálathoz a szakirodalomban megismert módszereket alkalmaztuk, lináris regressziót, valamint Owen-Shapley-dekompozíciót. Eredményeink azt mutatják, hogy az ESG-mutatók nem tekinthetők „részvényvakcinának” a vállalati válságállóság tekintetében, ugyanakkor statisztikailag szignifikáns változók az előrejelzés szempontjából. A kutatás kimenetele rávilágít a fenntarthatósági szempontok fontosságára a pénzügyi döntéshozatalban.
\end{abstract}

JEL-kódok: Go1, Q56, G30

Kulcsszavak: ESG, válságállóság, pandémia, lineáris regresszió, Owen-Shapleydekompozíció

1 Jelen publikáció az Európai Unió, Magyarország és az Európai Szociális Alap társfinanszírozása által biztosított forrásból az EFOP-3.6.3-VEKOP-16-2017-00oo7 azonosítószámú „Tehetségből fiatal kutató - A kutatói életpályát támogató tevékenységek a felsőoktatásban" című projekt keretében jött létre.

2 Dudás Fanni PhD-hallgató, Budapesti Corvinus Egyetem. E-mail: fanni.dudas@uni-corvinus.hu. Naffa Helena PhD, docens, Budapesti Corvinus Egyetem. E-mail: helena.naffa@uni-corvinus.hu. 


\section{BEVEZETÉS}

A Covid-19 világjárvány okozta világválság jelentős visszaesést okozott a globális részvénypiacokon 2020. február 20-ától folyamatosan. Ez a gazdasági sokk csaknem három hónapig tartott, míg a nemzetközi piacok a jegybankok segítségévél talpra tudtak állni 2020 májusára, köszönhetően a piacon megjelenő likviditásbőségnek. Mivel a járvány hosszú távú hatásai még nem ismertek, ez a tanulmány a Covid-19 válságának rövid távú hatásait vizsgálja az ESG-mutatók szerepének hangsúlyozásával.

Általánosságban elmondható, hogy szinte minden eszközosztály és részvénybefektetés hirtelen visszaesett, amikor a világjárványról szóló hírek felbukkantak, ugyanakkor az egyes ágazatok másképpen regáltak a válságra: voltak olyan ágazatok, amelyek a válság kedvezményezettjeivé váltak, míg másoknak továbbra is jelentős kihívást jelentett az életben maradás. Günther et al. (2020) szerint olyan cégek, mint a Lufthansa, az Adidas vagy az amerikai légitársaságok pénzügyi támogatást kértek a kormánytól, hogy likvidek maradjanak. A válság elsődleges haszonélvezői a technológiai cégek és az egészségügyi szektor szereplöi voltak. Ebben a helyzetben a jegybankok gyors fellépése jelentett megoldást: a gazdasági recessziótól való félelmet eloszlatta a gyors és jelentős likviditást biztosító jegybankok megjelenése, amelyek a laza fiskális politikát követve számos vállalatot megmentettek a csődtől. Jelen tanulmányban a 2020. február 20-a és 2020. májusa közötti rövid időszakot „Covid-válságnak” (CC) nevezzük. Ez a cikk a vállalatok válságtürő képességére összpontosít a CC során, különös tekintettel az ESGmetrikák szerepére.

Ebben a kutatásban a vállalatok fenntarthatóságát ESG-mérőszámokkal mérjük. A fenntartható pénzügyek napjaink egyik legújabb irányzata a pénzügy szakirodalmában, amely időben lemaradt a társtudományoktól a fenntarthatóság problémájának kutatásában (Naffa-Fain, 2020; Tamásné Vőneki-Lamanda, 2020). Ezzel szemben a makróközgazdászok már korábban is foglalkoztak fenntarthatósággal és fenntarthatóság pénzügyi vonatkozásival (Naffa-Fain, 2020; NémethDurkó, 2020). Napjainkban a fenntarthatósági és ESG-szempontok egyre inkább előtrébe kerülnek a befektetőknél. Számos kutatás vizsgálja a környezeti (E), a szociális (S) és a kormányzás $(G)$ faktorok kapcsolatát a különböző vállalati teljesítménymutatókkal (Primecz-Havran-Lakatos, 2019; Berlinger, Keresztúri-Tamásné Vőneki, 2019) A fenntartható gazdaságra való átállás azonban nem egyértelmű és könnyű út sem a befektetők, sem a vállalatok számára. A hosszú távú értékteremtés ellentétben áll a hagyományos befektetési megközelítéssel, amely a rövid távú profitszerzésre fókuszál, és csak a pénzügyi kockázatot veszi figyelembe. Ezzel szemben a hosszú távú értékteremtés integrálja a gazdasági, társadalmi, környezeti értékeket, és kezeli a pénzügyi, valamint fenntarthatósági kockázato- 
kat (Schoenmaker és Schramade, 2019). Ebben a cikkben a fenntarthatósági szempontokat a vállalatok ESG-mutatóival azonosítottuk. A környezeti, társadalmi és irányítási szempontokat összefoglalóan ESG-tényezőknek nevezzük, amelyek a közelmúltban kimagasló jelentőséggel bírnak a pénzügyekben. Az MSCI ESG Research (MSCI, 2016) szerint ezek egyedülálló teljesítménymutatók, amelyek egy befektetés fenntarthatóságát és társadalmi hatását mérik. Az ESG-mutatók mind a vállalatokra, mind az országokra vonatkozhatnak, hasonlóan a hitelminősítésekhez.

Számos kutató foglalkozott az ESG-teljesítmény szerepével a Covid-járvány alatt: bizonyítékot találtak arra, hogy a jó ESG-minősítés egyfajta védelmet nyújt a vállalatok számára; a szaksajtóban ESG-nek nevezték a CC elleni „részvényvakcinaként”. Ez a vállalati társadalmi felelősségvállaláson alapuló elmélet segít a társadalmi tőke és a vállalat iránti bizalom építésében. Ezek a kapcsolatok pedig arra ösztönzik majd a vállalat érintettjeit, hogy hüségesek maradjanak válság ideján is (Demers, 2021). Számos tanulmány támasztja alá ezt az elméletet, például Albuquerque et al., 2020; Bouslah et al., 2018; Cornett et al., 2016; Ding et al., 2020; 2021. Másrészt az ügynökelmélet alapján a kutatók ennek az ellenkezőjét tapasztalták: az ESG nem nyújt védelmet a válság idején a vállalatoknak (Lys et al., 2015).

Jelen tanulmány kutatási kérdése, hogy milyen szerepet játszanak az ESGszempontok a cégek ellenálló képességében a 2020. február 20. és 2020. május 1. közötti globális világjárvány első sokkjában, illetve, hogy van-e kapcsolat a vállalatok ESG-teljesítménye és válságtűrő képességük között. Először is megvizsgáljuk a válságtűrő képességet meghatározó tényezőket, és megvizsgáljuk, hogy az ESG-indikátorok alkalmazása javítja-e a modell magyarázó erejét. Ezután elemezzük az egyes regressziók R-négyzetének dekompozícióját, hogy meghatározzuk az egyes magyarázó változók pontos hozzájárulását az R-négyzethez (Izraeli, 2007). Vizsgálatunk során lineáris regressziót és Owen-Shapleydekompozíciót végeztünk. Eredményeink azt mutatják, hogy az ESG önmagában nem egy „részvényvakcinaként”, hanem statisztikailag szignifikáns és gazdaságilag fontos változóként tekinthető a járvány alatti hozamok magyarázatában.

A dolgozat a következőképpen épül fel: összefoglaljuk a releváns szakirodalmat, és bemutatjuk a az ESG-mutatók és a vállalati teljesítmény kapcsolatát válság idején. Ezt követően ismertetjük a hipotéziseket, a felhasznált adatbázist, és felvázoljuk az alkalmazott módszertant. A cikket a kutatási ereményekkel, valamint az eredmények értelmezésével zárjuk. 


\section{SZAKIRODALMI ÁTTEKINTÉS}

Az új koronavírus (Covid-19) nagy hatással volt a globális társadalmakra és a gazdaságokra, az általa okozott válság és helyreállítás napjainkban is folyik. A válság körül fellépő bizonytalanság miatt fokozottan szükség van megvizsgálni azokat jó gyakorlatokat, amelyek nagyobb ellenálló és adaptációs képességet eredményeztek a vállalatoknál, hogy a jövőben széleskörüen elterjedjenek ezek a példák. A válságrezilianciával országok és vállalatok szintjén is foglalkoztak korábban a szakirodalomban (Oprea et al., 2020; Alessi et al., 2020). Vállalati szinten eddig kevesen kutatták a gazdasági válság reziliencia-témakörét. Jellemzően regionális vagy országszinten vizsgálták eddig a kutatók ezt a jelenséget, ugyanakkor nagy szükség van a vállalatok szintjén is feltáró elemzésekre.

Sabatino (2016) kvalitatív eszközökkel vizsgálta meg a vállalatok ellenálló képességét, és az általa kifejlesztett modell segítségével meghatározta azokat a jellemzőket, amelyek definiálják a rugalmas vállalatot. Elemzése során hét tényezőt állapított meg: termékközpontosítás; földrajzi fokalizáció; gyors döntési képességek; klánmodell alapján szervező struktúra; erős nemzeti-üzleti értékek; ügyfélközpontúság; hatékony stratégiai célú ösztönző rendszer.

A pénzügyi ellenállóképességet szintén többen kutatták az elmúlt években. Soroka et al. (2020) a QuiScore hitelmutatót vizsgálták meg a vállalati és a regionális gazdasági ellenálló képesség mérésére. Egy esettanulmány keretében elemezték a mutató hasznosságát, és az eredmények azt mutatták, hogy a QuiScore hatékony mutatója a vállalatok gazdasági ellenálló képességének.

Markman és Venzin (2014) azt állítják cikkükben, hogy alapvetően kevés jó példa van a szakirodalomban arra, ami egy robusztus mérőszáma lenne a vállatok gazdasági ellenálló képességének. Tanulmányukban kidolgoztak egy egyedi válságellenállósági mutatót, amely egyesíti a pénzügyi teljesítmény mérőszámait a cégek volatilitási adataival. Eredményeik azt sugallják, hogy ezeknek a vállalatoknak az ellenálló képességét az erőforrás-képességük, a piaci kontextus és az ipari viszonyok kombinációja vezérli. A kutatásunk egyik célja nemcsak a jelenlegi helyzet vizsgálata, hanem a szakirodalom bővítése a vállalatok gazdasági ellenállóképességével kapcsolatban.

Több kutató vizsgálta az ESG-befektetéseket a koronavírus okozta válság alatt. Broadstock et al. (2021) azt a kutatási kérdést vizsgálták empirikus eszközökkel, hogy a vállalatok ESG-teljesítménye csökkenti a pénzügyi kockázatot válság idején. Eredményül azt kapták, hogy a magas ESG-pontszámú portfóliók általában jobban teljesítenek az alacsony ESG-portfóliókkal szemben.

Albuquerqe et al. (2020) azt elemezték, hogy a koronavírus okozta válság alatt a jobb környezeti és szociális (ES) besorolású cégek hogyan teljesítenek 2020 első 
negyedévében a többi céggel összehasonlítva. Kutatásuk során arra találtak bizonyítékot, hogy a magas ES-besorolású részvények hozama lényegesen magasabb, a hozamok volatilitása alacsonyabb és a kereskedési volumenük is nagyobb, mint más részvényeknél. A magas ES-besorolású és magas hirdetési kiadásokkal rendelkező cégek különösen jól teljesítenek a válság során. Ez a cikk kiemeli az ES politikáinak fontosságát a vállalatok ellenállóbbá tételében válság idején.

Armeanu et al. (2017) a vállalatok válságtürő képességeinek kockázatkezelési vonatkozásait vizsgálta. Úgy vélték, hogy a jó vállalatirányítás biztosítja a megfelelő kockázatkezelést, azaz válság esetén a vállalatok eléggé rugalmasak ahhoz, hogy a váratlan fenyegetésekre reagáljanak. Ezért az optimális kockázatkezelés olyan vállalati ellenálló képességet biztosít, amely egyfajta versenyelőnyt biztosít válság idején. A kutatók megvizsgálták Románia tőzsdén jegyzett társaságait, és megállapították, hogy a vezérigazgató neme, az igazgatóság létszáma és az auditbizottság léte negatívan befolyásolja a bukás kockázatát.

Castro és Zermeno (2020) olyan rezilienciatényezőket vizsgált, mint a válsággal kapcsolatos attitűdök, a vállalkozás és a vállalkozó jellemzői, az intézményekkel való kapcsolatok, valamint a humán és társadalmi tőkével, valamint a stratégiai menedzsmenttel való összefüggések. Úgy vélik, hogy ezeket a tényezőket kell figyelembe venni ahhoz, hogy egy rugalmas vállalkozói ökoszisztéma alakuljon ki, beleértve a különböző szereplőket, mint az egyetemeket és az őket támogató közpolitikai döntéshozókat.

Számos tudományos tanulmány foglalkozott az ESG-teljesítmény kockázatkezelő szerepével a válság időszakában. Godfrey et al. (2009) szerint bizonyos típusú CSR-tevékenységek nagyobb valószínüséggel generálnak goodwillt, és biztosításszerű védelmet nyújtanak a lefelé mutató kockázatokkal szemben, különösen válság idején.

Egyes kutatók bizonyítékot találtak arra vonatkozóan, hogy az ESG-be történő nagyobb befektetések azt eredményezhetik, hogy a társadalmilag felelős cégek kevésbé lesznek sebezhetőek válság idején. Például Ding et al. (2020) a vállalati jellemzők és a Covid-19 esetekre adott részvényárfolyam-reakciók közötti öszszefüggést értékelte. Megállapították, hogy a részvényáraknak a világjárvány okozta csökkenése enyhébb volt azoknál a cégeknél, amelyek (a) erősebbek voltak a 2020 előtti finanszírozásban (több készpénz, kevesebb adósság és jelentősebb nyereség), (b) kevésbé voltak kitéve a Covid-19-nek a globális ellátási láncokon keresztül, valamint az ügyfelek telephelyeit tekintve, (c) több CSR-tevékenységet végeztek és (d) kevésbé megrögzött vezetők irányítása alatt működtek. Később Ding et al. (2021) megerősítette korábbi eredményeit. A 2020-as eredményeken túl azt találták, hogy a családok, a nagyvállalatok és a kormányok által ellenőrzött cégek részvényeinek a hozama jobban teljesített, a fedezeti alapok és más vagyonkezelő társaságok tulajdonában lévő cégek pedig rosszabbul teljesítettek. 
Az eredményeik azt mutatták, hogy tőzsdék pozitívan árazzák a kis mennyiségü vezetői tulajdont, de negatívan a magas szintű vezetői tulajdont a világjárvány idején (Ding et al., 2021).

Günther et al. (2020) azt vizsgálta, hogy a pénzügyileg fenntartható cégek hogyan teljesítettek a koronaválságban. A pénzügyi fenntarthatóságot négy feltétel mentén mérték, és ezeket a méréseket az MSCI Europe 15 európai országából származó cégek széles mintájának befektetési portfólióira alkalmazták. Kutatásuk szerint a pénzügyileg fenntartható cégek teljesítménye 2019 júliusa és 2020 márciusa között felülmúlja a teljes piacot és az alacsony pénzügyi fenntarthatósággal rendelkező cégekét.

Bouslah et al. (2018) a globális pénzügyi válság (GFC) hatását vizsgálta egy vállalat kockázata és társadalmi teljesítménye közötti összefüggésre nem pénzügyi egyesült államokbeli cégek adatbázisa alapján. Azt találták, hogy a társadalmi teljesítmény és kockázat jelentősen eltér a válság időszakában (a válság utáni időszakban) a válság előtti időszakhoz képest. A társadalmi teljesítmény csökkenti a volatilitást a pénzügyi válság idején.

Cornett et al. (2017) a bankok vállalati társadalmi felelősségvállalása (CSR) és pénzügyi teljesítménye közötti kapcsolatra összpontosított a globális pénzügyi válság (GFC) összefüggésében. Eredményeik alátámasztják, hogy a bankokat általában jutalmazzák a társadalmi felelősségvállalásért, mivel a pénzügyi teljesítmény pozitívan és szignifikánsan kapcsolódik a CSR-pontszámokhoz.

Mások ezzel szemben ellenkező állásponton vannak: a negatív ügynökelmélet alapján arra a következtetésre jutottak, hogy az ESG-teljesítménybe történő nagyobb befektetések a cégeket kiszolgáltatottabbá teszik, aminek a hatására válság idején a cégek kiszolgáltatottabbak és kevésbé reziliensek lesznek. Ezen elmélet szerint az ESG-beruházások olykor csupán pazarló, vállalati kasszából finanszírozott, öncélú vezetői kiadások; részvényesi szempontból értékrombolók lehetnek (Demers et al., 2021). Lys et al. (2015) egyetértenek ezzel az elmélettel. Megállapították, hogy a vállalati társadalmi felelősségvállalási kiadások nem vállalati jótékonysági akciók, és nem is javítják a jövőbeni pénzügyi teljesítményt: az ESG-kiadások nem termelnek elegendő hozamot, és csökkentik a részvényesi értéket. 


\section{ELMÉLETI KERET}

Tanulmányunkban Martin (2012) gazdaságireziliencia-modelljét alkalmaztuk. Martin (2012) kidolgozott egy négyfázisú rugalmassági keretet, amelyben megvizsgálta a a regionális gazdaságok nagy recessziós sokkokra adott reakcióját; feltáró példaként a brit régiókat vette alapul. Martin a gazdasági ellenálló képességet sokk által kiváltott folyamatként értékelte, amely négy részre osztható: ellenállás, helyreállítás, megújulás és új irányok keresése. Az ellenállás a recesszióra adott, első közvetlen válaszra vonatkozik, és méri a hanyatlás intenzitását és mértékét. Összehasonlításképpen, a fellendülés arra a sebességre és mértékre utal, hogy a gazdaság hogyan tud visszalendülni a visszaesésből, és visszatérni az eredeti növekedési trendhez. Tekintve, hogy kutatásunk alapvetően rövid távú, a modellnek ezt a komponensét fogjuk vizsgálni.

Martin (2012) modelljét továbbfejlesztjük, hogy a fenntarthatósági szempontokat is tartalmazzák: a vállalati és pénzügyi adatok mellett az ESG-szempontokat is bevontuk magyarázó tényezőként. Az első ábra a kiegészített Martin modellt mutatja be (1. ábra).

1. ábra

A cikkben alkalmazott modell Martin (2012) rezilienciamodellje alapján

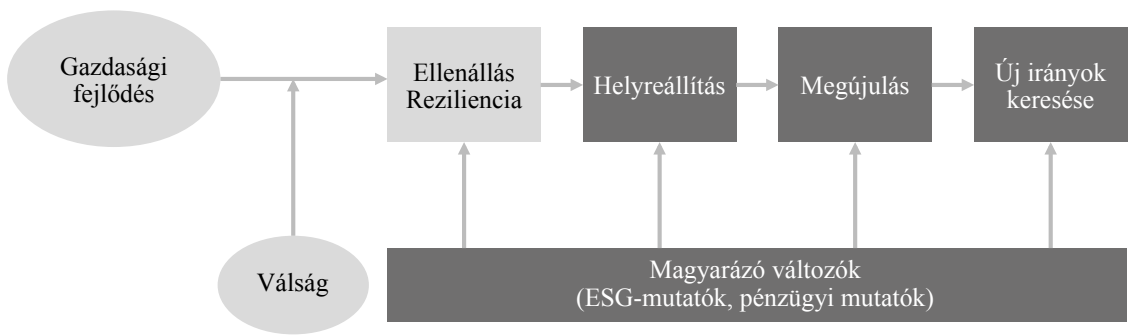

Forrás: Saját szerkesztés 


\section{MÓDSZERTAN ÉS ADATOK}

\subsection{Kutatási kérdés és hipotézisek}

A szakirodalom és az elméleti keret alapján az alábbi kutatási kérdést és hipotéziseket vizsgáljuk.

Kutatási kérdés:

- RQ: Javítják-e az ESG-mutatók a vállalatok válságállóságának mérését?

Hipotézisek:

- H1: Az ESG-mutatók szignifikáns változók, és javítják egy adott cég válságállóságának becslését.

- H2: A jobb ESG-teljesítmény javíthatja a vállalatok válságállóságát.

\subsection{Az adatbázis jellemzése}

Kutatásunk a vállalatok válságállóságának vizsgálatára fókuszál, kiemelve az azonosított ESG és pénzügyi tényezők relatív hozzájárulását a válságtűrő képesség magyarázatához. A vizsgálathoz számításokat végeztünk az MSCI World Indexben szereplö, közel 1000 cégen. Jelen helyzetben ez a vizsgálati csoport homogénnek tekinthető, hiszen a koronavírus okozta válság kezdeti visszaesése minden tőkepiacon hasonló módon ment végbe, ahogyan az a 2. ábrán is látható. Az ábra a különböző világpiaci indexek 2019. március és 2021. március közötti teljesítményét mutatja be. Az Euronext 100 egy európai részvényindex, a NYSE Composite és a Russel 2000 az Egyesült Államok indexei, a Shenzen Component egy kínai részvényindex, az IPC Mexico pedig egy mexikói index. 


\section{2. ábra}

\section{Különböző világpiaci indexek 2019 márciusa és 2021 márciusa között}

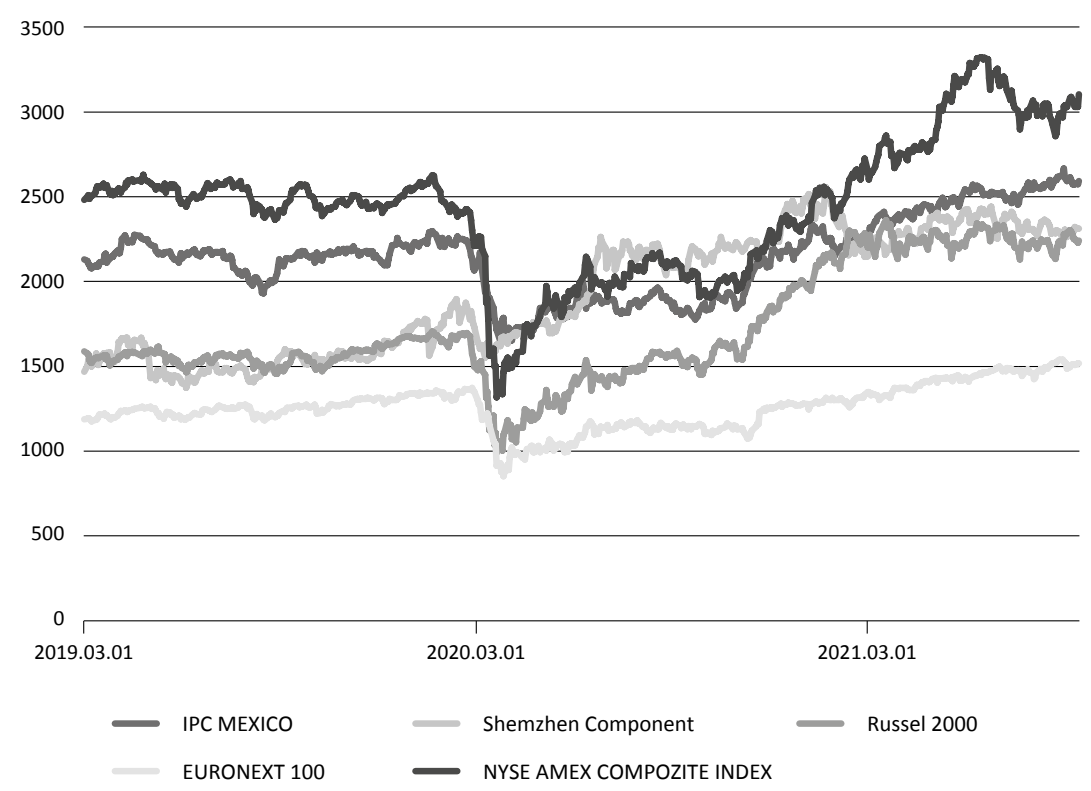

Forrás: Yahoo Finance, 2021

A válságból való kilábalás különböző módon történt az egyes régiókban és ágazatokban. Az elemzésünkhöz a Bloomberg pénzügyi adatait és a Sustainalytics ESG-adatait használtuk fel. Az időkeret a 2020. február 20-tól 2020. május 1-ig terjedő időszakot fedte le. A vonatkozó szakirodalom alapján a következő magyarázó változókat vettük fel, amelyeket az alábbi 1. táblázatban láthatunk. 


\section{1. táblázat}

\section{Magyarázó változók}

\begin{tabular}{|c|c|c|}
\hline $\begin{array}{l}\text { Változó } \\
\text { típusa }\end{array}$ & Változó neve & Definíció \\
\hline $\begin{array}{l}\text { Reziliancia- } \\
\text { indikátor }\end{array}$ & $\begin{array}{l}\text { Maximal } \\
\text { drawdown }\end{array}$ & $\begin{array}{l}\text { Részvényárfolyam csökkenése a legmagasabb } \\
\text { pontról a mélypontra a Covid-19 időszakban. } \\
\text { (2020. február 20. - 2020. május 1.) }\end{array}$ \\
\hline \multirow{8}{*}{$\begin{array}{l}\text { Pénzügyi } \\
\text { és vállalati } \\
\text { adatok }\end{array}$} & $\begin{array}{c}\text { Piaci } \\
\text { kapitalizáció }\end{array}$ & $\begin{array}{l}\text { A vállalat tőzsdei értéke, amely a vállalat } \\
\text { méretének mérésére szolgál (millió USD). }\end{array}$ \\
\hline & Méret & Piaci kapitalizáció logaritmusa. \\
\hline & $\mathrm{P} / \mathrm{E}$ ráta & $\begin{array}{l}\text { A P/E ráta a vállalat átlagosnak tekinthető, } \\
\text { az elmúlt három évre vonatkozó blended } \\
\text { forward kereseti várakozásának standardizált } \\
\text { havi PE adata, majd ebből az átlagból vettük } \\
\text { a legfrissebb értéket. }\end{array}$ \\
\hline & $\begin{array}{l}\text { Pénzügyi } \\
\text { tőkeáttétel }\end{array}$ & $\begin{array}{c}\text { Az átlagos eszközöket } \\
\text { az átlagos saját tőkéhez méri. }\end{array}$ \\
\hline & $\begin{array}{l}\text { Tobin } \\
\text { Q mutató }\end{array}$ & $\begin{array}{l}\text { Egy cég piaci értékének és a cég eszközeire } \\
\text { vonatkozó pótlási költségének aránya. }\end{array}$ \\
\hline & $\begin{array}{l}\text { Calmar- } \\
\text { mutató }\end{array}$ & $\begin{array}{c}\text { Az átlagos éves összetett megtérülési ráta és } \\
\text { a maximális lehívási kockázat összehasonlítása. } \\
\text { Minél magasabb a Calmar-arány, } \\
\text { annál jobban teljesített. }\end{array}$ \\
\hline & $\begin{array}{l}\text { Implicit } \\
\text { CDS }\end{array}$ & $\begin{array}{l}\text { Kockázati mérés a Bloomberg modellje } \\
\text { alapján. A Bloomberg-modellben alkalmazott } \\
\text { legfontosabb feltételezések a következök: } \\
\text { folyamatos a par töredékeként darabonként } \\
\text { állandó kockázatsemleges kockázati ráta, } \\
\text { és a nemteljesítési események statisztikailag } \\
\text { függetlenek a nemteljesítésmentes hozamgörbe } \\
\text { változásaitól (Wen-Kinsella, 2013). }\end{array}$ \\
\hline & Volatilitás & $\begin{array}{c}\text { A } 360 \text { napos áringadozás megegyezik a legutóbbi } \\
360 \text { kereskedési nap záróára relatív árváltozásának } \\
\text { évesített szórásával. }\end{array}$ \\
\hline
\end{tabular}




\begin{tabular}{|c|c|c|}
\hline $\begin{array}{l}\text { Változó } \\
\text { típusa }\end{array}$ & Változó neve & Definíció \\
\hline \multirow{5}{*}{ ESG-adatok } & $\begin{array}{l}\text { ESG-kockázati } \\
\text { pontszám }\end{array}$ & $\begin{array}{c}\text { A vállalat összesített kockázata } \\
\text { Az ESG-pontszámot a Sustainalytics } \\
\text { módszertana alapján számítjuk, ahol } \\
\text { az alacsonyabb szám alacsonyabb kockázatot } \\
\text { tükröz, azaz a jobb ESG-teljesítményt. }\end{array}$ \\
\hline & $\begin{array}{l}\text { ESG-menedzsment } \\
\text { pontszám }\end{array}$ & $\begin{array}{l}\text { ESG kockázatkezelési teljesítmény, amely jelzi } \\
\text { a teljes kezelhető kockázati kitettséget, milyen } \\
\text { a vállalatvezetés kockázatkezelési teljesítménye. }\end{array}$ \\
\hline & $\begin{array}{l}\text { Kombinált } \\
\text { vállalati incidensek } \\
\text { mérőszám }\end{array}$ & Vállalati ESG-incidensek száma \\
\hline & $\begin{array}{l}\text { ESG-kockázati } \\
\text { kategória }\end{array}$ & $\begin{array}{l}\text { Az ESG-kockázati besorolások azt mérik, } \\
\text { hogy a vállalat mennyire van kitéve az iparág- } \\
\text { specifikus lényeges ESG-kockázatoknak, és } \\
\text { azt, hogy a vállalat mennyire kezeli ezeket } \\
\text { a kockázatokat. A Sustainalytics az ESG-kockázat } \\
\text { súlyosságának öt kategóriáját azonosítja, amelyek } \\
\text { hatással lehetnek a vállalat vállalati értékére: } \\
\text { elhanyagolható, alacsony, közepes, magas, súlyos. }\end{array}$ \\
\hline & $\begin{array}{c}\text { ESG } \\
\text { vezető/lemaradó }\end{array}$ & $\begin{array}{c}\text { A vezető ESG-t figyelembe vettük, } \\
\text { ahol az ESG-kockázati kategória alacsony vagy } \\
\text { elhanyagolható volt, és az ESG-t lemaradónak } \\
\text { nyilvánítottuk, ha a kategóriájuk közepes, magas } \\
\text { vagy súlyos volt. Dummy változóként használjuk } \\
\text { 1-es értékkel, ha az ESG leader, és } 0 \text {-val } \\
\text { ESG-lemaradók esetén. }\end{array}$ \\
\hline
\end{tabular}

Forrás: Saját szerkesztés

Változóinkat a releváns szakirodalom alapján válogattuk be az elemzésekbe. Különféle példák vannak a válságállóság mérésére: Cheema-Fox et al. (2020) az összesített vállalati részvényhozam és az összesített országos részvényhozam különbségét használták magyarázó változónak munkájukban. Albuquerque et al. (2020) három különböző függő változót használtak elemzésükben, ezek: a negyedéves abnormális hozamok, a visszatérő volatilitás (teljes és idioszinkratikus volatilitás) és a működési teljesítmény (az eszközök megtérülésével, az üzemi nyereség és az eszközforgalom alapján mérve). Markman és Venzin (2014) saját metrikát dolgoztak ki a válságállóságra. Az ellenálló képesség mérésére a VOLARE-t (Volatilitás és ROE) használták, amelyek a volatilitást (kockázati mérték) és a hosszú távú ROE-t (jövedelmezőségi mérőszám) veszi figyelembe. A VOLARE objektívebb forráselosztási folyamatokat motivál, ahol a kockázatos kiadásokat vagy stratégi- 
ákat büntetik, míg a kevésbé kockázatos kezdeményezéseket jutalmazzák. Függő változóként a maximális lehívást alkalmaztuk De Melo Mendes-Lavrado (2017) definíciója és Hassan et al. munkája alapján (2021).

A független változók esetében a vállalati pénzügyi adatokat és az ESG-adatokat választottuk. A kiválasztott cég pénzügyi adatait Albuquerque et al. (2020) alapján közöltük. Az ESG esetében Demers et al. (2021) munkájával ellentétben, akik MSCI és EIKON refinitiv komplex ESG-méréseket használtak, mi a Sustainalytics adatbázis komplex mérőszámai mellett döntöttünk.

\subsection{Módszertan}

Ebben a kutatásban lineáris regressziós modellt alkalmaztunk, hogy feltárjuk az ESG-indikátorok prediktív erejét válságtűrő képesség esetén. Modellünkben a nemlinearitást algebrai linearizálással kezeltük, ami azt jelenti, hogy logaritmizáltuk a változókat abban az esetben, ha a változók pozitív értékűek voltak (Ferenczi, 2008).

Lineáris regressziót hajtottunk végre az IBM SPSS Statistics és a Gretl 2021d programban. Ezután Owen-Shapley-dekompozíciót használtunk, hogy meghatározzuk a magyarázó változók pontos hozzájárulását a lineáris regresszió R-négyzetéhez (Izraeli, 2007). Az Owen-Shapley-dekompozíciót a KNIME Workspaceben hajtottuk végre, és Python nyelvet használtunk.

\section{EREDMÉNYEK}

A válságtürő képesség meghatározó tényezőinek feltárására lineáris regressziót végeztünk, ahol a függő változó a maximális lehívás (maximal drawdown) volt. Először csak pénzügyi adatokat vettünk be a modellbe, majd az ESG-változókat is. Minden esetben forward módszert alkalmaztunk, mert ez a megközelítés csak a szignifikáns változókat tartalmazza a regressziós modellben. A forward algoritmus egy stabil megközelítés; minden esetben jelentősen növelheti a modell magyarázó erejét, miközben ez kevésbé pontos, mint a többi algoritmus (Bendel-Afifi, 1977).

A következő táblázat bemutatja az első regresszió eredményeit, amikor csak pénzügyi változók szerepeltek a modellben (2. táblázat). 


\section{2. táblázat}

Az első regresszió eredménye (1. modell)

\begin{tabular}{lccccc}
\hline & \multicolumn{2}{c}{ Sztenderdizált koefficiensek } & \multicolumn{2}{c}{ Kollinearitás statisztika } \\
& Beta & $\mathbf{t}$ & Sig. & Tolerancia & VIF \\
\hline Konstans & & 13,58801 & $9,14 \mathrm{E}-39$ & & \\
Volatilitás & $-0,686702532$ & $-29,3987$ & $5,4 \mathrm{E}-138$ & 0,725527 & 1,378309 \\
$\begin{array}{l}\text { Calmar- } \\
\text { mutató }\end{array}$ & 0,265366844 & 11,56833 & $3,64 \mathrm{E}-29$ & 0,752285 & 1,329284 \\
$\begin{array}{l}\text { P/E ráta } \\
\text { Tobin Q } \\
\text { mutató }\end{array}$ & $-0,201663635$ & $-9,72371$ & $1,98 \mathrm{E}-21$ & 0,920328 & 1,086569 \\
Méret & 0,140790409 & 5,944431 & $3,81 \mathrm{E}-09$ & 0,705681 & 1,417071 \\
$\begin{array}{l}\text { Pénzügyi } \\
\text { tókeáttétel }\end{array}$ & 0,091029833 & 4,125559 & $4 \mathrm{E}-05$ & 0,813078 & 1,229895 \\
\begin{tabular}{l} 
Implicit CDS \\
\hline
\end{tabular} & $-0,09867204$ & $-4,30405$ & $1,84 \mathrm{E}-05$ & 0,753184 & 1,327698 \\
\hline
\end{tabular}

Forrás: Saját szerkesztés

Ebben a regresszióban az R-négyzet 59,7\% volt. Az implikált CDS nem volt szignifikáns a modellben, míg a többi változó igen. A VIF-értékek mind 10 alatt voltak; ennek az alapján úgy értékeljük, hogy ebben a modellben nincs multikollinearitás. A következő esetben az ESG-mutatókat hozzáadtuk a regressziós modellhez. A 3. táblázat bemutatja a kapott eredményeket. 
3. táblázat

A második regresszió eredménye (2.modell)

\begin{tabular}{|c|c|c|c|c|c|}
\hline & \multicolumn{3}{|c|}{ Sztenderdizált koefficiensek } & \multicolumn{2}{|c|}{$\begin{array}{c}\text { Kollinearitás } \\
\text { statisztika }\end{array}$} \\
\hline & $\mathbf{t}$ & Sig. & Tolerancia & VIF & VIF \\
\hline Konstans & & 16,44379 & $4,79 \mathrm{E}-54$ & & \\
\hline Volatilitás & $-0,664368383$ & $-30,2636$ & $6,6 \mathrm{E}-144$ & 0,711609 & 1,405267 \\
\hline $\begin{array}{l}\text { Calmar- } \\
\text { mutató }\end{array}$ & 0,238995588 & 11,06528 & $5,98 \mathrm{E}-27$ & 0,73513 & 1,360303 \\
\hline $\begin{array}{l}\text { ESG- } \\
\text { menedzsment } \\
\text { pontszám }\end{array}$ & $-0,22030962$ & $-11,6094$ & $2,4 \mathrm{E}-29$ & 0,952296 & 1,050094 \\
\hline $\mathrm{P} / \mathrm{E}$ ráta & $-0,18222887$ & $-9,39122$ & $3,78 \mathrm{E}-20$ & 0,910812 & 1,097921 \\
\hline Tobin Q mutató & 0,114121337 & 5,057807 & $5,03 \mathrm{E}-07$ & 0,673612 & 1,484534 \\
\hline Méret & 0,132921063 & 5,942611 & $3,85 \mathrm{E}-09$ & 0,685466 & 1,458862 \\
\hline $\begin{array}{l}\text { Pénzügyi } \\
\text { tőkeáttétel }\end{array}$ & $-0,08627008$ & $-4,0274$ & $6,06 \mathrm{E}-05$ & 0,747391 & 1,337988 \\
\hline $\begin{array}{l}\text { Vállalalti } \\
\text { incidensek }\end{array}$ & $-0,065715838$ & $-3,15881$ & 0,001631 & 0,792366 & 1,262044 \\
\hline Implicit CDS & 0,061521789 & 2,716841 & 0,006703 & 0,66879 & 1,495239 \\
\hline $\begin{array}{l}\text { ESG-vezető/ } \\
\text { lemaradó } \\
\text { (dummy) }\end{array}$ & 0,003 & 0,1527 & 0,87866 & 1,51979 & 0,6476 \\
\hline $\begin{array}{l}\text { ESG-kockázati } \\
\text { pontszám }\end{array}$ & 0,009 & 0,43369 & 0,6646 & 1,1613 & 0,65805 \\
\hline
\end{tabular}

Forrás: Saját szerkesztés

A második futtatás során az ESG-kockázati pontszám és az ESG-vezető/lemaradó dummy változók nem kerültek be a modellbe, a többi változó igen. A VIFértékek mind 10 alatt voltak, azaz ebben a modellben nincs multikollinearitás.

Az R-négyzet 65,2\% volt, ami azt jelenti, hogy az ESG-szempont plusz magyarázó erőt adhat a modellünknek. Az eredmények azt sugallják, hogy egy vállalat kevésbé rugalmas, ha részvényei volatilisak, és pénzügyi tőkeáttétele magasabb. A magasabb $\mathrm{P} / \mathrm{E}$ arány rosszabb eredményeket eredményez a rugalmasság és az ESG-menedzsment pontszám tekintetében is, ami azt jelzi, hogy ha egy vállalat ESG-kockázatkezelése jobb, akkor a vállalat kevésbé lesz reziliens egy válság esetén. A vállalati incidensek együtthatója azt mutatja, hogy ha a viták száma 
nő, a vállalatok kevésbé lesznek ellenállóak. Másrészről a Tobin Q és Calmarmutatók bétái azt sugallják, hogy a túlértékelt részvények ellenállóbbak lehetnek. A dummy változó kizárása azt jelzi, hogy nincs szignifikáns különbség az ESGvezetők és a lemaradók között a válságállóság tekintetében.

Ahhoz, hogy jobban megértsük a szignifikáns változók relatív fontosságát a válságállóság tekintetében, Owen-Shapley-dekompozíciót alkalmaztunk, amint azt Israeli (2007) munkája is szemlélteti. Ezzel a megközelítéssel az egyes változók magyarázó szerepét mutatjuk be a két regresszió modell esetében: az egyes modellek R-négyzet értékét mely változó milyen mértékben magyarázza.

A 4. táblázat az egyes változókkal magyarázható 59,7\%-os R-négyzet felbontását mutatja be. Amint az látható, a volatilitás járul hozzá a legnagyobb mértékben a teljes R-négyzethez: 71,6\%-ot magyaráz csupán ez az egy változó a modell által magyarázott teljes varianciából. A P/E mutató a második az általa magyarázott variancia 8,88\%-ával. Ezután a Calmar-mutató következik 8,78\%-kal, majd a többi változó, a vállalatméret 4,87\%-kal, a Tobin Q 4,52\%-kal és a pénzügyi tőkeáttétel $1,34 \%$-kal.

A 2. modell esetében az ESG-változóknak a regresszióba való bevonásakor a következő eredményeket kaptuk, amelyeket az 5. táblázatban mutatunk be. A teljes R-négyzet 65,2\% volt, amelyhez a következőképpen járultak hozzá az egyes változók: a volatilitás ebben az esetben is a legnagyobb mértékben járult hozzá a teljes R-négyzethez, a magyarázott eltérés 56,28\%-a ennek a változónak volt köszönhető. Az ESG-menedzsment pontszám a második volt az általa magyarázott variáció 9,93\%-ával. Ezután a P/E mutató és az implikált CDS értékei 7,49\% és 7,09\% voltak, majd a többi változó következett, a Calmar-mutató 6,39\%, a vállalatméret $6,38 \%$, a Tobin Q mutató 3,32\%, a vállalati incidensek 2,19\% és végül a pénzügyi tőkeáttétel $0,94 \%$.

Összegezve az ESG-változók szerepeit a válságreziliencia meghatározásában, az ESG-menedzsment pontszám bizonyult a második legfontosabb változónak: az R-négyzet 65,2\%-os értékének a 9,93\%-ához járult hozzá, míg a vállalati incidenesek 2,19\%-tették ki a teljes R-négyzetnek.

Összességében ezekből a regressziós elemzésekből és az Owen-Shapleydekompozícióból származó eredményeink azt sugallják, hogy az ESG-változók - különösen az ESG-menedzsment pontszám - fontosak a Covid-válság alatti válságtürő képesség magyarázatában, és nem szabad figyelmen kívül hagynunk őket. 
4. táblázat

Az azonosított tényezők relatív hozzájárulása a válságtürő képesség magyarázatához az 1. modell esetében

\begin{tabular}{cc}
\hline Változó neve & Relatív hozzájárulás mértéke \\
\hline Volatilitás & $71,60 \%$ \\
P/E ráta & $8,88 \%$ \\
Calmar-mutató & $8,78 \%$ \\
Tobin Q mutató & $4,87 \%$ \\
Méret & $4,52 \%$ \\
Pénzügyi tőkeáttétel & $1,34 \%$ \\
\hline
\end{tabular}

Forrás: Saját szerkesztés

5. táblázat

Az azonosított tényezők relatív hozzájárulása a válságtürő képesség magyarázatához a 2. modell esetében

\begin{tabular}{cc}
\hline Változó neve & Relatív hozzájárulás mértéke \\
\hline Volatilitás & $56,28 \%$ \\
ESG-menedzsment pontszám & $9,93 \%$ \\
P/E mutató & $7,49 \%$ \\
Implicit CDS & $7,09 \%$ \\
Calmar-mutató & $6,39 \%$ \\
Méret & $6,38 \%$ \\
Tobin Q mutató & $3,32 \%$ \\
Vállalati incidensek & $2,19 \%$ \\
Pénzügyi tőkeáttétel & $0,94 \%$ \\
\hline
\end{tabular}

Forrás: Saját szerkesztés

Összességében a lineáris regressziós és az Owen-Shapley-féle dekompozíciós elemzéseink összesített eredményei átfogó képet adnak az ESG-változókról: ezek a tényezők potenciális rezilienciatényezők lehetnek a Covid-válság idején, mivel az ESG-mutatók plusz magyarázó erőt adhatnak a válságállósági modellekhez. Az eredmények azonban arra utalnak, hogy az ESG teljesítménye és a részvények teljesítménye közötti összefüggés nem egyértelmű. Nem találtunk bizonyítékot arra, hogy az ESG-vezetők és az ESG-elmaradottak között jelentős különbség 
lenne a válságállóság tekintetében. Másrészt a regressziós modell eredményei azt sugallják, hogy az ESG teljesítménye javíthatja és ronthatja is a vállalat válságállóságát.

Ezen eredmények alapján nem utasítottuk el azt a Hi hipotézist, hogy az ESGindikátorok szignifikáns és korábbi változók voltak egy adott cég válságtűrő képességének becslésében. Másrészt elvetettük azt a $\mathrm{H}_{2}$ hipotézist, hogy a jobb ESGteljesítmény javíthatja a vállalatok válságtűrő képességét.

\section{6. ÖSSZEGZÉS}

Ebben a kutatásban megvizsgáltuk az ESG-indikátorok szerepét a vállalati válságreziliencia magyarázatában a Covid-19 válság idején. A világjárvány 2020. februári kitörése jelentős külső sokként hatott a globális részvénypiacokra. Eredményeink azt mutatják, hogy az ESG-mutatókra nem tekinthetünk „részvényvakcinaként”, ugyanakkor az ESG-mutatók, konkrétan az ESGmenedzsment pontszám és a vállalati incidensek jó előrejelzői lehetnek a vállalati szintű válságállóságnak. Kutatásunk empirikus eredményei azonban arra is utalnak, hogy a jobb ESG-teljesítmény nem javítja egyértelműen a vállalatok válságreziliáját.

Eredményeink összhangban van a szakirodalommal: Ferriani és Natoli (2020) tanulmányukban kiemelték, hogy a befektetők jelentősen figyelembe vették az ESG-kockázatot a dötéseikben a Covid-19 válság idején. Ezen túl Diaz et al. (2021) kimutatták, hogy az ESG-szempontok nélkülözhetetlenek a befektetési döntések megértéséhez válság alatti időkben. Az ESG-mérőszámok és a vállalati válságreziliencia kapcsolata azonban még mindig nem egyértelmű; további empirikus tesztekre van szükség a kérdés mélyebb megértéséhez. Demers et al. (2021), valamint Liang és Renneboog (2020) is kiemelték munkájukban, hogy az ESG és a vállalati teljesítmények közötti kapcsolat megosztja a szakmai közösséget is.

Eredményeink rávilágítanak a fenntarthatósági szempontok fontosságára a válságreziliencia magyarázatában. A Schoenmaker és Schramade (2019) szerint fenntartható gazdaságra való áttérés szembemegy a hagyományos befektetési megközelítéssel, ami a rövid távú profitszerzést helyezi előtérbe, és csak a pénzügyi kockázatot veszi figyelembe. Ezzel szemben a hosszú távú értékteremtés integrálja a pénzügyi, társadalmi és környezeti értékeket, és nemcsak a pénzügyi, hanem a fenntarthatósági kockázattal is foglalkozik - erre jó példa a Covid-válság, amely felhívja a figyelmet a fenntarthatósági szempontok fokozott figyelembevételére. Dijk (2020) megfelelő alapot ad munkájában a fenntarthatósági kockázat mérésével és kezelésével kapcsolatban, amit a gyakorlatban kell a jövőben továbbfejleszteni. 


\section{HIVATKOZÁSOK}

Albuquerque, R. - Koskinen, Y. - Yang, S. - Zhang, C. (2020): Resiliency of environmental and social stocks: An analysis of the exogenous COVID-19 market crash. The Review of Corporate Finance Studies, 9(3), 593-621. https://doi.org/10.1093/rcfs/cfaao11.

Alessi, L. - Benczur, P. - Campolongo, F. - Cariboni, J. - Manca, A. R. - Menyhert, B. - PaGANO, A. (2020): The resilience of EU member states to the financial and economic crisis. Social Indicators Research, 148(2), 569-598. https://doi.org/10.1007/s11205-019-02200-1.

Armeanu, D. Ş. - Vintilă, G. - Gherghina, Ş. C. - Petrache, D. C. (2017): Approaches on correlation between board of directors and risk management in resilient economies. Sustainability, 9(2), 173. https://doi.org/10.339o/su9020173.

Bendel, R. B.,-Afifi, A. A. (1977) Comparison of stopping rules in forward "stepwise" regression. Journal of the American Statistical Association, 72(357), 46-53. https://doi.org/10.1080/01621459 .1977 .10479905 .

Berlinger, E. - Keresztúri, J. L. - Tamásné Vöneki, Zs. (2018) A cross-country analysis of operational risk: The effect of the freedom of press. In PRMIA Hungary Chapter Éves Konferenciája, 8.

Bloomberg (2021): Global Indices. Available at: Bloomberg Terminal. Accessed: 20 July 2021.

Broadstock, D. C. - Chan, K. - Cheng, L. T. - Wang, X. (2021): The role of ESG performance during times of financial crisis: Evidence from COVID-19 in China. Finance Research Letters 38 , 101716. https://doi.org/10.1016/j.frl.2020.101716.

Bouslah, K. - Kryzanowski, L. - Bouchra, M. Z. (2018): Social performance and firm risk: Impact of the financial crisis. Journal of Business Ethics, 149, 643-669. https://research-repository.st-andrews.ac.uk/bitstream/handle/10023/8244/Bouslah_JBE2016_SocialPerformance_ cc.pdf? sequence $=1$ \&isAllowed $=y$.

Castro, M. P. - Zermeño, M. G. G. (2020): Being an entrepreneur post-COVID-19-resilience in times of crisis: a systematic literature review. Journal of Entrepreneurship in Emerging Economies, https://doi.org/10.1108/jeee-07-2020-0246.

Cheema-Fox, A. - LaPerla, B. R. - Serafeim, G.,-Wang, H. S. (2020): Corporate resilience and response during COVID-19. Available at SSRN 3578167, https://doi.org/10.2139/ssrn.3578167.

Demers, E. - Hendrikse, J. - Joos, P. - Lev, B. (2021): ESG did not immunize stocks during the COVID-19 crisis, but investments in intangible assets did. Journal of Business Finance \& Accounting, 48(3-4), 433-462. https://doi.org/10.1111/jbfa.12523.

DíAz, V. - Ibrushi, D. - Zhao, J. (2021): Reconsidering systematic factors during the COVID-19 pandemic - The rising importance of ESG. Finance Research Letters, 38, 10187o. https://doi. org/10.1016/j.frl.2020.101870.

Ding, W. - Levine, R. - Lin, C. - XIE, W. (2021): Corporate immunity to the COVID-19 pandemic. Journal of Financial Economics, 141(2), 802-830. https://doi.org/10.1016/j.jfineco.2021.03.005.

Ding, W. - Levine, R. - Lin, C. - XIE, W. (2020): Corporate immunity to th COVID-19 pandemic (No. w27055). National Bureau of Economic Research. https://doi.org/10.3386/w27055.

European Commission (2021a): Sustainable Finance. Available at https://ec.europa.eu/info/businesseconomy-euro/banking-and-finance/sustainable-finance_en.

European Commission (2021b): Corporate sustainability reporting. Available at https://ec.europa. $\mathrm{eu} /$ info/business-economy-euro/company-reporting-and-auditing/company-reporting/ corporate-sustainability-reporting_en.

Ferenczi, T. (2008): Nemlineáris modellek [online]. Available at http://www.medstat.hu [online] (letöltve: 2021.10.20.). 
Ferriani, F. - Natoli, F. (2020): ESG risks in times of COVID-19. Applied Economics Letters, 1-5. https://doi.org/10.1080/13504851.2020.1830932.

Godfrey, P. C. - Merrill, C. B. - Hansen, J. M. (2009): The relationship between corporate social responsibility and shareholder value: An empirical test of the risk management hypothesis. Strategic Management Journal, 30, 425-445. https://onlinelibrary.wiley.com/doi/pdfdirect/10.1002/ smj.750.

Günther, T. - Gleissner, W. - Walkshäusl, C. (2020): What happened to financially sustainable firms in the Corona crisis?. In Sustainability Management Forum/Nachhaltigkeits Management Forum, 28(3), 83-90. Heidelberg-Berlin: Springer. https://doi.org/10.1007/s00550-020-00503-3.

Hassan, M. K. - Chowdhury, M. I. H. - Balli, F.,-Hasan, R. (2021): A note on COVID-19 instigated maximum drawdown in Islamic markets versus conventional counterparts. Finance Research Letters, 102426. https://doi.org/10.1016/j.frl.2021.102426.

IsRAELI, O. (2007): A Shapley-based decomposition of the R-square of a linear regression. The Journal of Economic Inequality, 5(2), 199-212. https://doi.org/10.1007/s10888-006-9036-6.

Liang, H. - Renneboog, L. (2020): Corporate social responsibility and sustainable finance: A review of the literature. European Corporate Governance Institute - Finance Working Paper, 701. https://doi.org/10.2139/ssrn.3698631.

Lys, T. - NAughton, J. P. - WANG, C. (2015): Signaling through corporate accountability reporting. Journal of Accounting and Economics, 60, 56-72. https://www.sciencedirect.com/science/article/ pii/So165410115000191.

Markman, G. M. - Venzin, M. (2014): Resilience: Lessons from banks that have braved the economic crisis - And from those that have not. International Business Review, 23(6), 1096-1107. https://doi.org/10.1016/j.ibusrev.2014.06.013.

MARTIN, R. (2012): Regional economic resilience, hysteresis and recessionary shocks. Journal of economic geography, 12(1), 1-32. https://doi.org/10.1093/jeg/lbro19.

De Melo Mendes, B. V. - Lavrado, R. C. (2017) Implementing and testing the Maximum Drawdown at Risk. Finance Research Letters, 22, 95-100. https://doi.org/10.1016/j.frl.2017.06.001.

MSCI (2016), MSCI ESG Government Ratings. Available at https://www.msci.com/documents/10199/ eog2c439-34e1-4055-8491-86fbo799c38f

NAffa, H. - FAIN, M. (2020): Performance measurement of ESG-themed megatrend investments in global equity markets using pure factor portfolios methodology. PLoS ONE, 15(12), 1-34. https:// doi.org/10.1371/journal.pone.0244225.

Németh-Durkó, E. (2020): Környezet és pénzügyek: A pénzügyi fejlettség emissziót befolyásoló szerepe. Gazdaság és Pénzügy, 7(4), 434-449. https://doi.org/10.33926/gp.2020.4.4

Oprea, F. - Onofrei, M. - Lupu, D. - Vintila, G. - Paraschiv, G. (2020): The determinants of economic resilience. The case of Eastern European regions. Sustainability, 12(10), 4228. https:// doi.org/10.339o/su12104228.

Primecz, H. - Havran, D. -Lakatos, Z. (2019). How Does Female Presence on the Management and Supervisory Boards Impact the Performance in CEE? Academy of Management Annual Meeting Proceedings, 2019(1), 1-1. https://doi.org/10.5465/ambpp.2019.10602abstract.

Sabatino, M. (2016): Economic crisis and resilience: Resilient capacity and competitiveness of the enterprises. Journal of Business Research, 69(5), 1924-1927. https://doi.org/10.1016/j. jbusres.2015.10.081.

Schoenmaker, D. - Schramade, W. (2019) Investing for long-term value creation. Journal of Sustainable Finance and Investment, 9(4), 356-377. https://doi.org/10.1080/20430795.2019.1625012.

Soroka, A. - Bristow, G. - NAim, M. - Purvis, L. (2020): Measuring regional business resilience. Regional Studies, 54(6), 838-850. https://doi.org/10.1080/00343404.2019.1652893. 
TAMÁSNÉ VŐNEKI, Zs. - LAMANDA, G. (2020). Az ESG-kockázatokkal kapcsolatos banki közzétételek tartalomelemzése - Pillanatkép a hazai nagybankok közzétételi gyakorlatáról. Gazdaság és Pénzügy, 7(4), 420-433. https://bankszovetseg.hu/Public/gep/2020/420-433\%20Tamasne\%20 VZS.pdf.

VAN Dijk, M. A. (2020): Assessing climate risk for investment portfolios. Available at https://www. netspar.nl/assets/uploads/Session-2c_Van-Dijk.pdf.

Wen, Y. - Kinsella, J. (2013): Credit Default Swap-Pricing Theory, Real Data Analysis and Classroom Application Using Bloomberg Terminal. New York, https:/data.bloomberglp.com/ bat/sites/3/2016/10/WhitePaper_Wen.pdf.

Yahoo Finance (2021) World Indices. Available at https://finance.yahoo.com/world-indices?.tsrc=finsrch (letöltve: 2021.10.20.). 